\title{
WASTEWATER AND LEACHATE TREATMENT IN TARTU WASTE WATER TREATMENT PLANT
}

\author{
Harri Terase \\ Tartu Waterworks Ltd, Head of Wasterwater Treatment Plant, Estonia \\ Jüri Haller \\ Tartu Waterworks Ltd, Head of Laboratory, Estonia
}

\begin{abstract}
History

Legislation

Technical datas

Nitrogen removing problems

Tartu landfill leachate treatment possibilities
\end{abstract}

\section{HISTORY}

Tartu Veevärk (Tartu Waterworks) was established by Tartu City Council as an outgrowth from the municipal company Tartu Veevärk by its degree no. 62 of 1997.02.06., and all shares of Tartu Veevärk Ltd are owned by the city of Tartu.

Tartu Wastewater Treatment plant was designed in Moscow in 1982-1983, the construction works began in September 1985 but were soon stopped. The works started again in summer 1994. The mechanical treatment started in November 1996 and biological treatment in December 1998 . Today ca $80 \%$ of Tartu wastewater is coming to the plant, the rest is coming after two years when the building of collecting collector will be finished.

\section{TECHNICAL DATAS OF TARTU WASTEWATER TREATMENT PLANT}

Project: Rate of flow $Q=40000 \mathrm{~m}^{3} / \mathrm{d} ; \mathrm{Q}_{\max }=5000 \mathrm{~m}^{3} / \mathrm{h}$

Real: Rate of flow $\quad Q=11000-73000 \mathrm{~m}^{3} / \mathrm{d}$

Table 1

\begin{tabular}{|lc|c|c|}
\hline \multicolumn{2}{|c|}{ Inlet } & Project & Real \\
\hline $\mathrm{BOD}_{7}$ & $\mathrm{mg} / \mathrm{l}$ & 250 & $150-250$ \\
\hline $\mathrm{SS}$ & $\mathrm{mg} / \mathrm{l}$ & 240 & $250-350$ \\
\hline $\mathrm{P}_{\text {tot }}$ & $\mathrm{mg} / \mathrm{l}$ & 5 & $7-15$ \\
\hline $\mathrm{N}_{\text {tot }}$ & $\mathrm{mg} / \mathrm{l}$ & 25 & $30-50$ \\
\hline
\end{tabular}


Table 2

\begin{tabular}{|lc|c|c|}
\hline \multicolumn{2}{|c|}{ Outlet } & Project & Real \\
\hline $\mathrm{BOD}_{7}$ & $\mathrm{mg} / \mathrm{l}$ & 15 & $4-10$ \\
\hline $\mathrm{SS}$ & $\mathrm{mg} / \mathrm{l}$ & 15 & $7-12$ \\
\hline $\mathrm{P}_{\text {tot }}$ & $\mathrm{mg} / \mathrm{l}$ & 1,5 & $0,6-3,0$ \\
\hline $\mathrm{N}_{\text {tot }}$ & $\mathrm{mg} / \mathrm{l}$ & - & $15-30$ \\
\hline
\end{tabular}

\section{LEGISLATION}

Estonian Pollution Charge Act (passed on 10 February 1999, entered into force 21 March 1999) provides the rates of the charge to be paid for the release of pollutants or waste into the environment and the procedure for the calculation and payment of the charge.

Regulation No. 269 of July 2001 of the Government of the Republic of Estonia "Requirements for Waste Water Discharged into Water Bodies or into Soil" establishes the requirements for directing effluent into water body or soil and enacts the measures to control the fulfilment of these established requirements depending on the size of pollution load. Pollution load coming from the source of pollution is expressed in population equivalent (PE) and is calculated on the basis of the average pollution load per year. Population equivalent is a unit of conditional pollution load caused by a person during a 24 hour-period which, when expressed by $\mathrm{BOD}_{7}$, is $60 \mathrm{~g}$ of oxygen. There are some different outlet limit values and degrees of purification for different pollution load (for example below or over $100000 \mathrm{PE}$ ) in current regulation (Table 3). It is very important for us, because the pollution load coming from source of pollution of Tartu city is $92500 \mathrm{PE}$ at the moment.

Table 3

\begin{tabular}{|c|c|c|c|c|}
\hline \multirow{2}{*}{ Ingredient } & \multicolumn{4}{|c|}{ Pollution load coming from source of pollution } \\
\cline { 2 - 5 } & \multicolumn{2}{|c|}{$\mathrm{PE}=2000-100000$} & \multicolumn{2}{c|}{$\mathrm{PE}>100000$} \\
\cline { 2 - 5 } & $\begin{array}{c}\text { Limit value } \\
\text { (outlet) } \\
\mathrm{mg} / \mathrm{l}\end{array}$ & $\begin{array}{c}\text { Degree of } \\
\text { purification } \\
\%\end{array}$ & $\begin{array}{c}\text { Limit value } \\
\text { (outlet) } \\
\mathrm{mg} / \mathrm{l}\end{array}$ & $\begin{array}{c}\text { Degree of } \\
\text { purification } \\
\%\end{array}$ \\
\hline $\mathrm{BOD}_{7}$ & 25,0 & 80 & 15,0 & 90 \\
\hline $\mathrm{COD}$ & 125,0 & 75 & 125,0 & 75 \\
\hline Suspended solids & 35,0 & 75 & 15,0 & 90 \\
\hline $\mathrm{P}_{\text {tot }}$ & 2,0 & 70 & 1,0 & 80 \\
\hline $\mathrm{N}_{\text {tot }}$ & - & - & 10,0 & $70-80$ \\
\hline
\end{tabular}

\section{PROBLEMS}

The greatest problem of our treatment plant is nitrogen removing because this was not actual seven years ago in Estonia. Before over designing in 1994-1996 most of the basins' parts were already built. Rebuilding all constructions was very expensive, so the problem solving was put in the future as starting of the plant was found to be most important. We have done some experiments to find the best way to decrease the nitrogen content in outlet of the plant. In order to achieve the nitrogen removing effect we need $\left(70-80 \%\right.$ or $\mathrm{N}_{\text {tot }}<10 \mathrm{mg} / \mathrm{l}$ in outlet), we would have to rise up the concentration of activated sludge in aeration tanks 2-3 times and spend two times more electrical energy. With rising the concentration of activated sludge we 
would have to face another problem - not enough space for secondary sedimentation and in rainy days a problem with activated sludge in outlet.

The alternative way to remove the nitrogen is to use wetland. The location of the Tartu Wastewater Plant is suitable for that, but we would have to solve the environmental problem (favorable nesting area for rare birds).

Tartu city government asked our opinion about treatment of Tartu landfill leachate in our plant. According to the information provided by firm administering Tartu landfill the flow rate of this leachate is about $22500 \mathrm{me}^{3} /$ month $\left(750 \mathrm{~m}^{3} /\right.$ day $)$. We made leachate analysis in November and December last year. The results of the analyses are given in Table 4.

\section{Table 4}

\begin{tabular}{|c|c|c|}
\hline Ingredient & Unit & Analytical results \\
\hline COD & $\mathrm{mgO} / \mathrm{l}$ & $480-1000$ \\
\hline $\mathrm{BOD}_{7}$ & $\mathrm{mgO} / \mathrm{l}$ & $30-60$ \\
\hline $\mathrm{P}_{\text {tot }}$ & $\mathrm{mg} / \mathrm{l}$ & $3,0-4,0$ \\
\hline $\mathrm{N}_{\text {tot }}$ & $\mathrm{mg} / \mathrm{l}$ & $170-320$ \\
\hline Suspended solids (SS) & $\mathrm{mg} / \mathrm{l}$ & $5-13$ \\
\hline $\mathrm{SO}_{4}{ }^{2-}$ & $\mathrm{mg} / \mathrm{l}$ & $59-86$ \\
\hline $\mathrm{Cl}^{-}$ & $\mathrm{mg} / \mathrm{l}$ & $940-1100$ \\
\hline Oil products & $\mathrm{mg} / \mathrm{l}$ & $<0,05-1,1$ \\
\hline Phenols & $\mathrm{mg} / \mathrm{l}$ & $0,025-0,12$ \\
\hline $\mathrm{pH}$ & & $7,20-7,61$ \\
\hline $\mathrm{Hg}$ & $\mu \mathrm{g} / \mathrm{l}$ & $<0,10$ \\
\hline $\mathrm{Cd}$ & $\mu \mathrm{g} / \mathrm{l}$ & $<0,10$ \\
\hline $\mathrm{Pb}$ & $\mu \mathrm{g} / \mathrm{l}$ & $<1,0-1,0$ \\
\hline As & $\mu \mathrm{g} / \mathrm{l}$ & $10-11$ \\
\hline $\mathrm{Cr}$ & $\mu \mathrm{g} / \mathrm{l}$ & $79-86$ \\
\hline $\mathrm{Cu}$ & $\mu \mathrm{g} / 1$ & $8,0-10$ \\
\hline $\mathrm{Zn}$ & $\mu \mathrm{g} / \mathrm{l}$ & $<20$ \\
\hline
\end{tabular}

These analytical results confirmed our suggestion that the main problems are not connected with heavy metals, but with high nitrogen, COD and low BOD content. We decided that low organic matter content and relatively high COD content in leachate would be eliminated after the building of collecting collector is ready, that is when the rest of Tartu city wastewater (the last $20 \%$ ) is coming to our plant and the high organic matter content wastewater of Tartu Brewery (one of the biggest in Estonia) will be treated in our wastewater treatment plant too. Otherwise the amount of the sold water has decreased 2,9 times and rendered wastewater services 2,75 times during the last 10-year period in Tartu (Figure 1 and Figure 2). Main reasons for this are: increase in the price of water supply and of wastewater services, modernization of the production technology, closing of enterprises and decrease in the number of population. Our experience has showed the increase in wastewater inlet BOD content during the last years. The continuing decrease in water use in Tartu city is first of all causing the thickening of the domestic wastewater. 


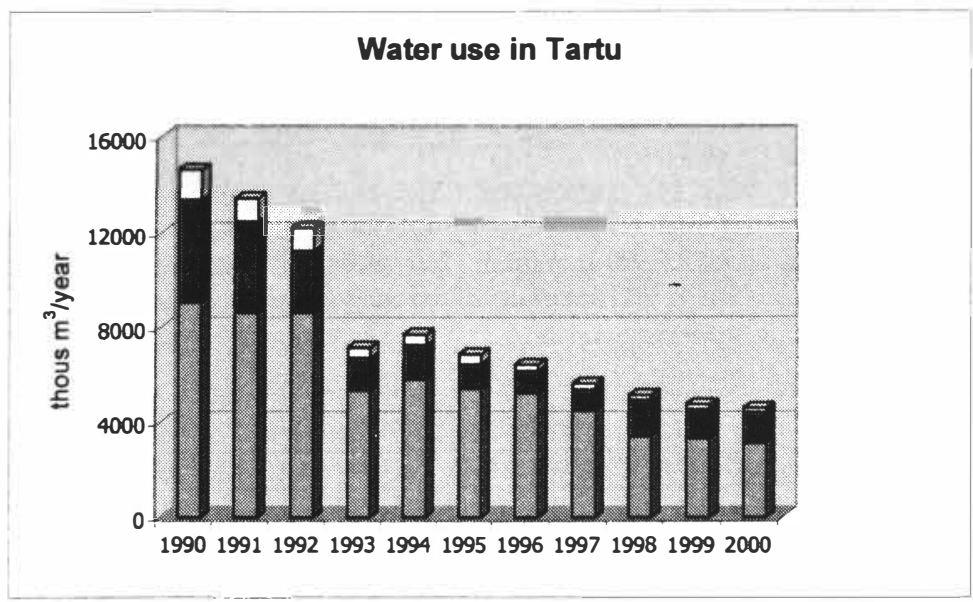

Figure 1. Water use in Tartu in 1990-2000 $\square$ domestic, $\square$ industry, $\square$ other Source: Tartu keskkond 2001

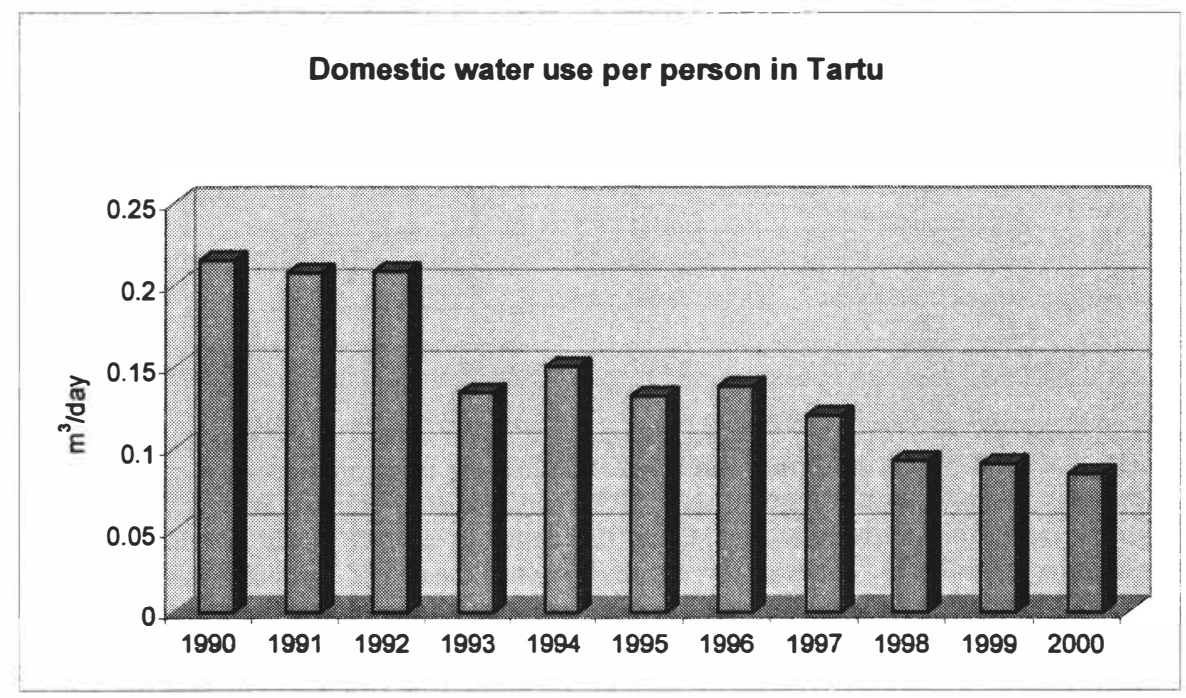

Figure 2. Domestic water use in Tartu per person in 1990-2000. Source: Tartu kesktond 2001

Considering preceding we have made calculations and reached a conclusion that it is possible to treat the leachate in our plant regardless of increasing (up to 20\%) nitrogen concentration in inlet of the plant. But as the service is quite expensive, the designers have started to find alternative ways to solve the problem. 